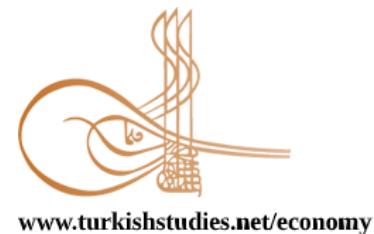

Turkish Studies - Economics, Finance, Politics

\title{
Muhasebe Meslek Mensuplarının Muhasebe Standartlarına Bakış Açıları ve Farkındalıkları Üzerine Bir Araştırma: Erzurum İli Örneğii
}

\author{
A Research on Awareness and Overview to Accounting Standards of Accounting Professional \\ Members: A Sample of Erzurum
}

\author{
Muhammed Ardıç**
}

\begin{abstract}
Accounting Standards are an important development for the world of accounting and finance and are applied in many countries at certain levels. While these standards meet the needs of developed countries in content, some problems arise in practice in developing countries. Different practices emerging in the implementation of laws and regulations that direct accounting cause problems for accounting professionals. It can be said that determining the thoughts of the accountants who are practitioners and the difficulties they face will make a positive contribution to the success of the application. For this purpose, a determination of the developing countries, although not literally implementation started thinking about accounting standards or expectations for the glitch in the application of the accounting profession in Turkey is of importance. For this purpose, a survey was carried out for the accounting professional members who were registered in erzurum city center and who actually performed the profession and the results were evaluated with SPSS Statistics 19 Program. According to the results of the study; Depending on the increase in the level of knowledge and education, the internalization of standards by professionals will lead to an increase in the level of success. Also study results; It has revealed the importance of increasing harmonization between institutions and laws regarding accounting practices, that the need for qualified personnel will increase with the expansion of the field of practice, the level of education is still not sufficient, and many problems can be solved with harmony between institutions. As a result, this study aims to empirically evaluate the perspectives of accounting professionals in Erzurum city center on accounting standards.
\end{abstract}

Structured Abstract: Introduction It can be said that the UMS/IFRS set is in line with the needs and conditions of countries developed as scope and qualification. However, some problems are not missed in practice at the point of compliance with legislation in developing countries. In this context, it is important to determine what the thinking or expectations of the accounting professionals in Turkey, a developing country of ums/ifrs set, are applicable. In particular, in determining the reasons for not being implemented in all sectors still operating in our country as of 2018, identifying the thinking sustenance of the accounting professions in the case of the practitioner and identifying the limits it encounters will provide positive contributions to the application success.

\footnotetext{
* Bu çalışmanın literatür kısmı Artvin Uluslararası Sosyal Bilimler Kongresinde bildiri olarak sunulmuştur.

** Dr. Öğr. Üyesi, Artvin Çoruh Üniversitesi, İşletme Fakültesi, Sağlık Yönetimi Bölümü

Asst. Prof. Dr. Artvin Coruh University, Faculty of Management, Department of Health Management ORCID 0000-0002-2439-7247

ardic@artvin.edu.tr

Cite as/ Atıf: Ardıç, M. (2020). Muhasebe meslek mensuplarının muhasebe standartlarına bakış açıları ve farkındalıkları üzerine bir araştırma: Erzurum ili örneği. Turkish Studies - Economy, 15(3), 1163-1178. https://dx.doi.org/10.47644/TurkishStudies.43605

Received/Geliş: 15 May/Mayıs 2020

Accepted/Kabul: 20 September/Eylül 2020

Copyright $($ INTAC LTD, Turkey

Checked by plagiarism software

Published/Yayın: 25 September/Eylül 2020

CC BY-NC 4.0
} 
The information and some of the issues that are related to some of the work on the members of the profession and the standards can be summarized as follows

- Accountants do not know enough accounting standards and there are lackof information in practice,

- The problems affecting the implementation of TFRS are the revision of standards frequently, prioritizing tax concerns and changing investor demands and expectations.

- Professional accountants do not have sufficient training on accounting standards.

- The professional accountants have sufficient knowledge about TFRS, but the training provided for the implementation of standards is not sufficient.

- $\quad$ TFRS implementations will increase the workload of professional accountants.

\section{Method}

In this study, it was preferred to use the face-to-face interview method to collect primary data more reliably and quickly from the professional accountants who make up the research universe. In this framework, a questionnaire was applied to the members of the profession in order to reveal their views and awareness of the accounting standards of the members of the profession who are active in the city center of Erzurum.

In the questionnaire used in the study, there are 27 questions in total, 4 of which are questions for learning the personal information of professional accountants, 9 about awareness of accounting standards and 14 questions about the perspective of accounting standards.

\section{Findings}

The data obtained from the survey can be summarized as follows.

- What is your level of knowledge about accounting standards? The average of the answers given to the question seems to be close to 3,837 .

- Have you received any corporate training related to Accounting Standards? $74.4 \%$ of the professions answered yes, and $25.6 \%$ answered yes.

- Who should provide training on Accounting Standards? "65.1\% of the professional accountants suggested TÜRMOB.

- Would you attend a training on Accounting Standards? 91.9\% of the professional accountants answered yes, $4.7 \%$ answered no.

- How many years does it take for professional accountants to absorb accounting standards and apply them to the financial reporting process?" The average of the responses of professional accountants to the question is 3,825 .

- What is the most important problem to be encountered in the process of applying accounting standards? professional accountants answered the question that the workload will increase.

- What would be the contribution of the application of accounting standards to our country? To the question, professional accountants emphasize the decline of the informal economy $(61.6 \%)$.

- Education should be increased to facilitate the transition process of accounting standards to implementation.

- In the evaluations reflecting the opinions of the professional accountants regarding the importance of their judgment regarding accounting standards, the highest value was expressed as the need to increase the need for qualified personnel.

- According to the $\mathrm{t}$ test result regarding the accounting standards of professional accountants, "Accounting standards will increase the need for qualified personnel in enterprises", there is a significant relationship between gender and the proposition $(\mathrm{p}<0,05)$. 
- According to the results of the t test conducted by the professional accountants for the proposition "It is correct to bring the accounting standards to the fore in the new TCC", a significant relationship has been found between education and the proposal in question $(\mathrm{p}<0,05)$.

- In order to be successful in the application of accounting standards, penalties should be brought to the fore "According to the results of the $t$ test regarding the proposition, a significant relationship was found between the professional seniority and the proposition in question.

\section{Conclusion and Suggestions}

The studies conducted for the accounting profession in Turkey with the financial reporting standards similar results when evaluated in most studies shows that in general obtained.

When the results of the study are evaluated, the prominent points are:

- Increasing the level of knowledge and education will increase the implementation and success of the standards by internalizing them by professional accountants. In this context, it may be beneficial to carry out educational activities in the literature on TFRS implementations and in collaboration with TÜRMOB and University, which are prominent institutions in this study.

- It was stated that TFRS practices will increase the workload of professional accountants in general and create extra workload both in this study and in the literature. Increasing the transactions made in electronic environment such as e-Ledger and e-Invoice can be accepted as measures to reduce workload. With the dissemination of electronic transactions to all business activities subject to accounting, it can be expected that the workload will decrease completely.,

- Another issue highlighted in the study is that increasing the compliance between institutions and laws regarding accounting practices will eliminate many problems. In the current sense, accounting practices are under the influence of tax legislation and various studies are carried out in order to achieve standardization in the field of accounting. Although some arrangements have been made, the arrangements that will eliminate the multiple financial table arrangements of the companies regarding financial reporting and provide coordination between the Tax Procedure Law and the Turkish Commercial Code are insufficient. As a result, this situation keeps the standards issue up to date.

- The average of the answers given to the question "What is your level of knowledge about accounting standards?" And the average of the suggestion "there is a lack of knowledge in the field of accounting standards of professional accountants" in the Likert scale supports each other.

- The average of the responses regarding the level of knowledge about accounting standards and the average of the recommendation that "professional accountants have a lack of knowledge in the area of accounting standards" support each other. This result reveals once again the need to increase the level of education on standards.

Keywords: Accounting Standards, Accounting Professional Members, Accounting Education

Öz: Muhasebe Standartları muhasebe ve finans dünyası için önemli bir gelişme olup belirli düzeylerde olmak üzere pek çok ülkede uygulanmaktadır. $\mathrm{Bu}$ standartlar içerik olarak gelişmiş ülkelerin ihtiyaçlarını karşılamakta iken gelişmekte olan ülkelerde uygulamada mevzuatlardan kaynaklanan bazı sorunlar ortaya çıkmaktadır. Muhasebeye yön veren kanun ve mevzuatların uygulanmasında ortaya çıkan farklı uygulamalar muhasebe meslek mensuplarının sıkıntı yaşamasına neden olmaktadır. Özellikle uygulayıcı durumundaki muhasebecilerin düşünceleri ve karşılaştığı sıkıntıların tespit edilmesinin uygulama başarısına olumlu katkılar yapacağı söylenebilir. Bu amaçla gelişmekte olan bir ülke olan Türkiye'de tam anlamıyla olmasa da uygulanmasına başlanılan muhasebe standartları hakkında muhasebe meslek mensuplarının uygulamadaki aksaklıklara yönelik düşünceleri veya beklentilerinin tespiti önem arz etmektedir. Bu amaçla Erzurum il merkezine kayıtlı olan ve fiili olarak mesleği icra eden muhasebe meslek mensuplarına yönelik anket uygulaması yapılmış ve sonuçları SPSS Statistics 19 Programı ile değerlendirilmiştir. Çalışma sonuçlarına göre; bilgi düzeyi ve eğitimin artmasına bağlı olarak standartların meslek mensuplarınca içselleştirilerek uygulanması başarı düzeyini artmasına neden olacaktır. Ayrıca çalışma sonuçları; muhasebe uygulamaları ile 
ilgili kurumlar ve kanunlar arası uyumun arttırılmasının önemini, uygulama alanının genişletilmesiyle birlikte kalifiye eleman ihtiyacını artacak olmasını, eğitim düzeyinin halen yeterli olmamasını ve birçok problemin kurumlar arası uyumu ile çözülebileceğini ortaya koymuştur. Sonuç olarak bu çalışmada, Erzurum il merkezinde bulunan muhasebe meslek mensuplarının muhasebe standartlarına dair bakış açılarının ampirik olarak değerlendirilmesi amaçlanmaktadır.

Anahtar Kelimeler: Muhasebe Standartları, Muhasebe Meslek Mensupları, Muhasebe Eğitimi

\section{Giriș}

Küresel ekonomiye bağlı olarak ortaya çıkan önemli değişimler, uluslararası entegrasyonu benimseyen ve gelişmekte olan ülkelerin gösterdiği direnci kırma noktasında önemli bir firsat olarak görülmektedir. Muhasebe uygulamaları noktasında Türkiye'de son yıllarda önemli değişimler meydana gelmiş ve muhasebe standartlarında, muhasebe uygulamalarında ve finansal raporların hazırlanmasında uluslararası birlikteliğin sağlanmasında önemli mesafeler kat edilmiştir. $\mathrm{Bu}$ değişimler sonucunda ortaya çıkan güçlü bir finansal raporlama işletmelere şu faydaları sağlayabilir(Selimoğlu 2008):

- Karşılaştırılabilir bir finansal raporlama yapısı,

- Uluslararası girişimcileri teşvik etmek,

- Sermaye maliyetini azaltmak,

- Kaynak dağ 1 lımının etkinliğini yükseltmek,

-Ekonomik büyüme oranını yükseltmek.

Muhasebe standartları ile ilgi ortaya çıkan gelişmeler iş dünyasının muhasebe meslek mensuplarından beklentilerinin de değişimine sebep olmuştur. Türk Ticaret Kanunundaki güncelleme ile beraber güvenilir finansal raporlama ve denetim odaklı muhasebe anlayışına geçilmiştir. Dolayısıyla muhasebecilik mesleği bilgi ve beceri yelpazesi genişleyen bir meslek haline gelmiştir (Arsoy ve diğ., 2014).

Uluslararas1 Muhasebe Standartları (UMS/UFRS), güvenilir finansal raporlama ve denetim odaklı muhasebe anlayışının oluşumunda muhasebe ve finans dünyası için önemli bir gelişmedir. $\mathrm{Bu}$ noktada Türkiye'de de muhasebe standartlarının benimsenmesiyle ilgili düzenlemeler yapılagelmektedir. Söz konusu düzenlemeler toplumun birçok kesimini doğrudan ya da dolaylı olarak ilgilendirmektedir. Bu yeni düzenlemelere uyum sağlama hususunda tartışmasız en çok meslek mensuplarına önemli görevler düşmektedir. Meslek mensuplarının bugüne kadar ki uygulamalarda yaşanan sorunlar hakkındaki düşünceleri sürece katkı sağlaması açısından önem arz etmektedir. Sorunun çözümüne yönelik atılacak erken adımlar hem zaman hem de kaynak tasarrufu sağlayacaktır.

Muhasebe Standartları muhasebe ve finans dünyası için önemli bir gelişme olup belirli düzeylerde olmak üzere pek çok ülkede uygulanmaktadır. Bu standartlar içerik olarak gelişmiş ülkelerin ihtiyaçlarını karşılarken, gelişmekte olan ülkelerde uygulamada mevzuatlardan kaynaklanan bazı sorunlar ortaya çıkmaktadır. Bu amaçla gelişmekte olan ülkelerden biri olan Türkiye'de tam anlamıyla olmasa da uygulanmasına başlanılan muhasebe standartları hakkında muhasebe meslek mensuplarının uygulamadaki aksaklıklara yönelik düşünceleri veya beklentilerinin tespiti önem arz etmektedir. Sonuç olarak gelinen nokta itibariyle ülkemizde faaliyet gösteren tüm sektörlerde muhasebe standartlarının hangi düzeyde uygulandığ 1 ve uygulamada karşılaşılan sorunların tespitinde en önemli mihenk taşı olan muhasebe meslek mensuplarının düşünceleri ve karşılaştıkları sıkıntıların tespit edilmesi, uygulamanın daha geniş bir tabana yayılması hususunu önemli kılmaktadır. 


\section{Literatür}

Muhasebe Standartları ile ilgili olarak farklı profillere sahip meslek mensuplarının TMS/TFRS ile ilgili uygulamada yaşadıkları tecrübelere yönelik çalışmalar sürekli olarak yapılmaktadır. Literatürdeki meslek mensuplarını ve standartları konu alan literatür çalışmaları şöyledir;

Civan ve Kara'nın (2002) yaptığı çalışmada; meslek mensuplarının muhasebe standartları hakkında yeterli bilgiye sahip olmadıkları ve bilgi eksikliğinden kaynaklı sorunların var olduğu ifade edilmiş̧tir.

Ağca (2003) tarafindan yapılan ve Sermaye Piyasası Kurulu'nun yetki verdiği denetim şirketlerinde uygulanan anket çalışmasının sonucunda; Türkiye'de TMS/TFRS'ler için uygun ortamın henüz oluşmamış olduğu ifade edilmiştir.

Gönen ve Uğurluel (2007) tarafindan yapılan çalışmada, TMS/TFRS uygulamasına yönelik sorunlar olduğunu tespit edilmiş ve çözüm anlamında Muhasebe Sistemi Uygulama Genel Tebliği'nin revize edilmesi gerekliliği ortaya konulmuştur.

Bekçi'nin (2007) çalışması; muhasebe standartlanı konusunda meslek mensuplarına yeterli eğitimler verilmediği ve standartların uygulamasına yönelik olarak da eğitim kurumlarının beklenen katkıyı sunmadığını ortaya koymaktadır. Ayrıca meslek mensupları standartların uygulanmasına bağlı olarak iş yüklerinin artacağını düşünmektedirler.

Evci'nin (2008) çalışmasında ise; TMS/TFRS'lerin uygulanmasında iç ve dış kaynaklı çeşitli sorunlar olduğu ve eğitim düzeyinin uygulamanın önündeki en önemli engel olduğu ifade edilmektedir.

Acar vd.'nin (2009) yaptığı çalışmada ise; meslek mensupları standartların uygulanmasının mesleğin önemini artıracağını ifade etmişlerdir.

Erdoğan ve Dinç (2009) çalışmalarında; meslek mensuplarının 2/3'nün standartlardan haberdar olduğu ve yetersiz bilgiye sahip oldukları tespit etmişlerdir.

Elitaş vd.'nin (2011) çalışmasında ise; diğer çalışmalardaki sonuçların aksine meslek mensuplarının büyük bir çoğunluğunun (\%80) TMS hakkında yeterli bilgiye sahip oldukları fakat uygulamaya yönelik yeterli eğitim verilmediği vurgulanmıştır.

Hacıhasanoğlu vd.'nin (2012) çalışmalarında ise; standartların işletmelere pozitif katkı sağlayacağı ancak standartların uygulanmasının aynı zamanda iş yükünün artıracağını tespit etmişlerdir.

Bengü ve Çelik (2014) yaptıkları araştırma sonucunda; deneyimli olan meslek mensuplarına göre sık sık güncellenen standartların sorun çıkaracağı tespit etmişlerdir.

Yel ve Erdem (2015) tarafindan Bolu ilinde faaliyet gösteren muhasebe meslek mensuplarına yönelik yapılan çalışmada; meslek mensuplarının TFRS hakkındaki farkındalık, bilgi düzeylerinin ve TFRS'den beklentilerinin de yüksek olduğu ortaya çıkmıştır.

Boyar ve Güngörmüş̧ün (2016) yapısal eşitlik modeli kullanılarak yaptıkları çalışmada; meslek mensuplarının TFRS' ye bakış açılarının olumlu olduğu ve meslek mensuplarının TFRS bilgi düzeylerinin yeterli olduğu görülmektedir.

Akyüz ve Yeşil (2017) tarafindan çalışmada öne çıkan en önemli konu meslek mensuplarının standartlara yönelik yeterli bilgi ve uygulamaya yönelik eğitim eksikliğinin olmasıdır. Ayrıca çalışmada uygulamanın iş yükünü artıracağı ve buna bağlı olarak mesleği bırakma noktasında olumsuz düşünceler ortaya çıkacağı vurgulanmıştır. 


\section{Muhasebe Standartlarının Oluşumu ve Gelişimi}

Ulusal muhasebe standartları, "Bir ülke içinde uygulama birliği sağlamak amacıyla konulan ve ülkedeki kurum ve işletmelerinin finansal tablolarında, o ülke içinde geçerli yasalara uygun bir şekilde düzenlenen ve tekdüzen hesap çerçevesinde oluşan yasa ile bütünlenen ve uygulanması istenen bir sistem olarak (Yazıc1, 2003)" tanımlanmaktadır.

Ülkelerin muhasebe sistemleri o ülkenin muhasebe teorileri ve yasal düzenlemeleri ile etkileşim içerisindedir. Ülke genelinde ortak muhasebe uygulaması standartlar ile ancak mümkün olabilir (Şen, 2006).

Muhasebe standartlarının özellikleri şöyle sıralanabilir (Sağlam vd. 2008);

- Uygulanabilir ve anlamlı muhasebe bilgileri ortaya koymalıdır.

- Finansal performansla ilgili kullanılabilir ve güvenilir ölçümler ortaya koymalıdır.

- Muhasebe standartları uygulanabilirliği noktasında pratik olmalıdır

- Muhasebe standartları tutarlı olmalı, açık ve net ifade edilmelidir.

- Muhasebe standartlarının ikincil uygulamaları olmamalıdır. Ancak farklı uygulama gerektiğinde finansal performansa ve risk yönetimi faaliyetlerine yönelik kapsamlı olacak şekilde gerekli açıklama talep edilmelidir.

- Muhasebe standartları gelişmekte olan piyasalarda içinde uygulanmalıdır.

\section{Dünyada ve Türkiye'de Uluslararası Muhasebe Standartları}

Globalleşme uluslararası yatırımların artmasına ve her yerde aynı anlamı ifade eden şeffaf ve karşılaştırma imkanı sağlayan yeni bir muhasebe dili ortaya çıkmasına sebep olmuştur. Yaşanan bu gelişmeler uluslararası muhasebe standartlarının oluşumunun önünü açmış, uyum ve uyumlaştırma süreçlerinin hızlanmasına neden olmuştur (Kocamaz, 2012).

Uluslararası arenada yaşanan bu gelişmeler belli riskler çerçevesinde firmaların birden fazla ülkeye menkul kıymet ihraç etmesine imkân tanımıştır. Bu bağlamda yatırımcılar için yatırım yapılan ülkenin uygulamalarının bilinmesi ve finansal bilgilerine güvenilmesi önem arz etmektedir. $\mathrm{Bu}$ yüzden yatırımcılar açısından mali tabloların gerçeği yansıtıp yansıtmadığı muhasebe standartları çerçevesinde sürekli sorgulanmaktadır (Akdoğan,2003).

Uluslararası Muhasebe Standartları Kurulu (IASB) tarafindan çıkarılan UFRS'ler tüm dünyada yayılmakta ve ülkeler düzenlemelerini UFRS'lerle uyumlaştırma noktasında çalışmalar yapmaktadırlar (Uysal,2006). UFRS'ler uluslararas1 alanda ortak muhasebe ve finansal raporlama seti olarak kabul edilmektedir. Birçok ülke UFRS'leri ya olduğu gibi kendi dillerine çevirerek uygulamakta ya da Türkiye'de uygulanan TFRS gibi UFRS'lere paralel standartlar hazırlamaktadırlar (Sağlam vd,2008).

Dünyada değişik düzeylerde UFRS'ler uygulanmakla birlikte Türkiye'de Türkiye Muhasebe Standartları Kurulu (TMSK) tarafindan 2002 yılında UFRS'yi benimseme kararı alınmış ve UFRS'ler Türkçe 'ye çevrilmiştir. Bu bağlamda TMS SPK'ya tabi şirketlerde vergi kanunlarından bağımsız olarak 2005 yılından bu yana zorunlu olarak uygulamaktadır. Ayrıca 1

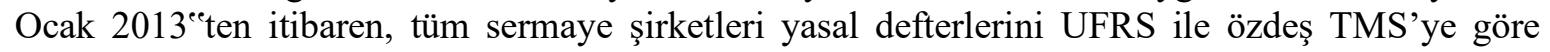
tutmak zorundadırlar. 


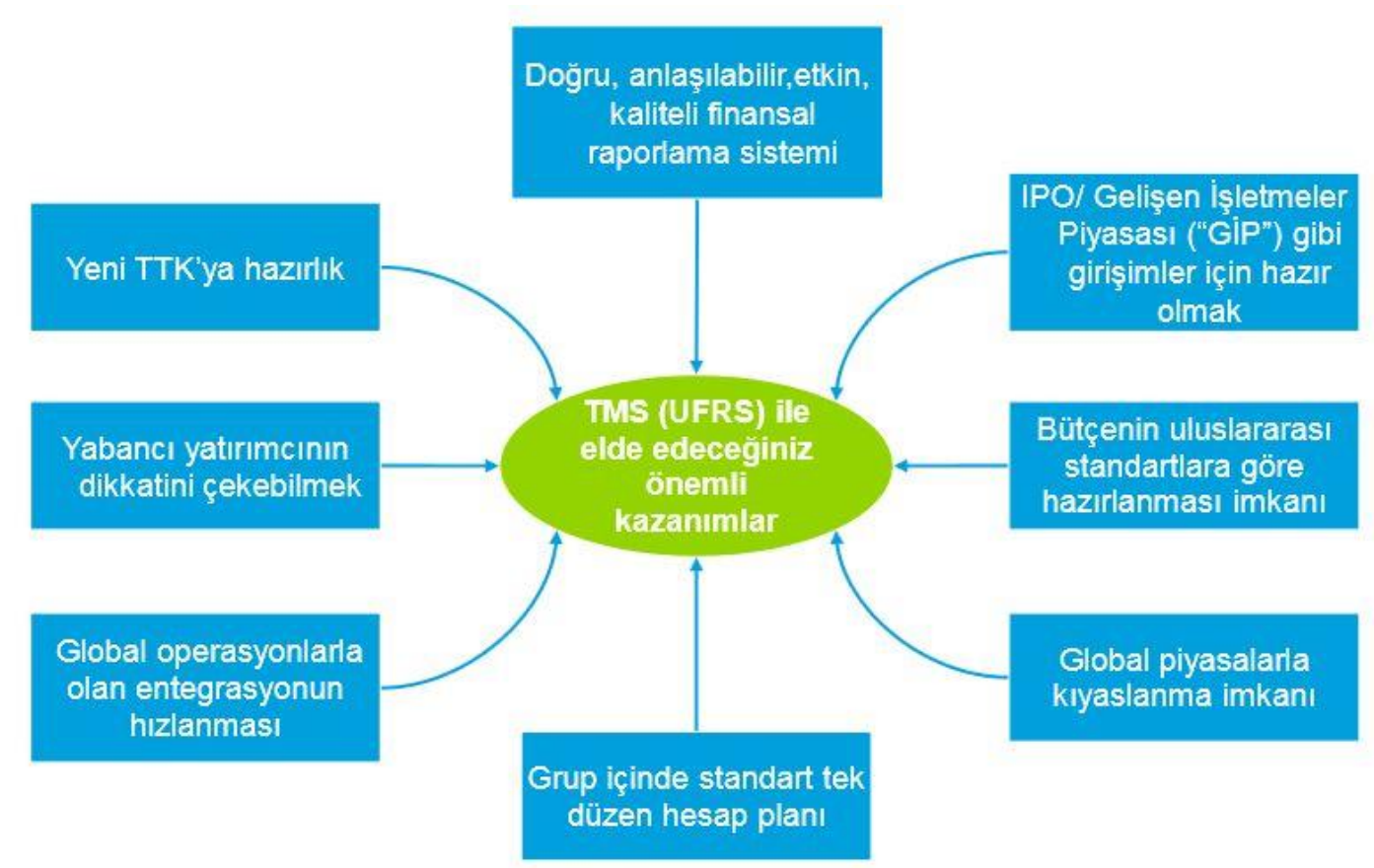

Şekil 1. TMS'nin Sağlayacağı Faydalar (Kaynak:www.denetimnet.net)

\section{Materyal ve Yöntem}

Çalışma konusuna bağlı veri toplama yöntemi olarak anket, gözlem ve mülakat gibi farklı araçlar kullanılabilmektedir (Kalıpsız, 1994; Karasar, 2009; Daşdemir, 2016). Bu araştırmada, verileri daha güvenilir ve hızlı bir şekilde toplanmak için muhasebe meslek mensupları ile yüz yüze görüşmeye dayalı anket yöntemi kullanılmıştır.

$\mathrm{Bu}$ çerçevede Erzurum il merkezinde faaliyette bulunan ve fiili olarak mesleği icra eden meslek mensuplarının muhasebe standartlarına bakış açıları ve farkındalıklarını ortaya koymak üzere söz konusu meslek mensuplarına anket uygulanmıştır.

Veriler anket yönetimi ile elde edilmiştir. Anket formları geliştirilirken daha önce akademisyenler üzerinde gerçekleştirilen Aktürk ve Akcanlı, (2014) araştırmasının anket sorularından istifade edilerek sorular meslek mensuplarına uygun hale getirilmiş ve yeniden güncellenmiştir. Çalışmada kullanılan anket formunda toplam 27 soru bulunmakta olup, bunların 4 tanesi meslek mensuplarının kişisel bilgilerini, 9 tanesi muhasebe standartları hakkındaki farkındalığını ve 14 soru ise muhasebe standartlarına bakış açısını öğrenmeye yönelik sorulardır.

Erzurum il merkezinde fiili olarak faaliyet gösteren muhasebe meslek mensuplarına ulaşılabileceği düşünülerek tam sayım yöntemi ile anketlerin uygulanmasına karar verilmiştir. Anket uygulamalarında fiili olarak mesleği icra etmeyenlere anket uygulaması yapılmamıştır ayrıca bazı kişiler anketi yanıtlamak istememişlerdir. Çalışmada evreninin hepsine ulaşılmaya çalışılmıştır. Süreç sonunda toplamda 86 anket toplanabilmiştir. İlgili kurumlardan alınan bilgiler doğrultusunda fiili olarak 143 kişin mesleği icra ettiği dikkate alındığında anketlerin cevaplanma oranı yaklaşık \%60 olarak gerçekleşmiştir.

Verilerin içsel tutarlılığı için yapılan güvenilirlik analizinde alfa katsayısı yöntemine başvurulmuştur. Alfa katsayısı 0,738 olduğu için araştırmada kullanılacak verilerin güvenilir olduğu söylenebilir. 
Çalışma sonucu elde edilen anket verileri tablo halinde getirilip frekans ve yüzde oranları yardımıyla araştırma yorumlanmıştır. Çalışmada elde edilen veriler "SPSS 19.0 for Windows" paket program yardımıyla analiz edilmiştir. Erzurum il merkezinde faaliyette bulunan meslek mensuplarının;

- Demografik özelliklerinin frekans ve yüzde dağılımı,

- Meslek mensuplarının Muhasebe Standartları hakkındaki farkındalıkları,

- Muhasebe standartlarına bakış açıları,

olmak üzere üç başlıkta elde edilen yargıların aritmetik ortalamaları ve standart sapmaları hesaplanmıştır. Çalışmada bazı meslek mensuplarının fiili olarak mesleği icra etmemesi bazılarının da çalışmaya katılmak istememesi çalışmanın kısıtlarını oluşturmaktadır.

\section{Bulgular ve Tartışma}

\section{Meslek Mensuplarının Demografik Özellikleri}

Çalışmada ilk önce çalışanların kişisel özelliklerin belirlenmiş ve anket sonuçları sonucunda elde edilen veriler değerlendirmeye alınmıştır. Bu değerlendirme sonucunda elde edilen sayısal dağılımlar Tablo 1'de gösterilmiştir.

Tablo 1: Demografik özellikler

\begin{tabular}{lccc} 
& Gruplar & N & \% \\
\hline \multirow{2}{*}{ Cinsiyet } & Erkek & 68 & 79.1 \\
& Kadın & 16 & 18.6 \\
& Toplam & $\mathbf{8 4}$ & $\mathbf{1 0 0}$ \\
\hline \multirow{3}{*}{ Yaş } & 25 ve altı & 1 & 1.2 \\
& $25-35$ & 14 & 16.3 \\
& $35-45$ & 34 & 39.5 \\
& 45 ve üstü & 36 & 41.9 \\
Eğitim & Toplam & $\mathbf{8 5}$ & $\mathbf{1 0 0}$ \\
& Lise & 5 & 5.8 \\
& Önlisans & 3 & 3.5 \\
& Lisans & 69 & 80.2 \\
& Yüksek Lisans & 9 & 10.5 \\
Mesleki Kıdem & Toplam & $\mathbf{8 6}$ & $\mathbf{1 0 0}$ \\
& $1-5$ y1l & 10 & 11.6 \\
& 6-10 y1l & 17 & 19.8 \\
& $11-20$ yil & 29 & 33.7 \\
& 20 yıl üstü & 27 & 31.4 \\
& Toplam & $\mathbf{8 3}$ & $\mathbf{1 0 0}$ \\
\hline
\end{tabular}

Tablo 1'de görüldüğü üzere ankete katılanların \%79.1'i erkek, \%18.6'sı kadındır. Ankete katılan çalışan grupların yaş dağılımının 25 yaş üzeri olduğu görülmekle birlikte yaş ortalamasının $\% 82$ 'sinin 35 ve üzeri olduğu, meslek mensuplarının eğitim seviyelerinin \%69'nun lisans mezunu olduğu ve mesleki kıdemlerinin \%88'inin 10 yıl ve üzeri olduğu görülmektedir.

\section{Muhasebe Standartları Hakkındaki Farkındalıkları}

Muhasebe meslek mensuplarının muhasebe standartları hakkındaki farkındalıklarının ölçüldüğü bu bölümde;

- Muhasebe standartları hakkındaki bilgi düzeyiniz nedir? sorusuna verilen yanıtların ortalamasının 3,837 yani iyiye yakın olduğu görülmektedir. Standart sapmanın da 0,528 olması da görüş farklılığının az olduğunu göstermektedir. 
Tablo 2: Meslek Mensuplarının Bilgi Düzeyleri

\begin{tabular}{|c|c|c|c|}
\hline & Frekans & $\%$ & $\begin{array}{c}\text { Sayi: 86 } \\
\text { Ortalama: 3,8372 } \\
\text { Standart Sapma: ,52827 }\end{array}$ \\
\hline Az & 1 & 1,2 & \multirow{2}{*}{} \\
\hline Orta & 17 & 19,8 & \multirow{2}{*}{73,3} \\
\hline İyi & 63 & 5,8 & \\
\hline Çok iyi & 5 & 100,0 & \\
\hline Toplam & 86 & & \\
\hline
\end{tabular}

- Muhasebe Standartlarına ilişkin herhangi bir kurumsal eğitim aldınız mı? sorusuna meslek mensuplarının \% 74.4'ü evet, \% 25.6'sı hayır cevabını vermiştir.

- Muhasebe Standartlarına ilişkin verilecek bir eğitimi kimin düzenlemesi uygun olur?" sorusuna meslek mensuplarının (\% 65.1) TÜRMOB'u, (\% 14) KGK'y1 ve (\% 11.6) Üniversiteyi ön plana çıkarmaktadır. Akademisyenlere yönelik Aktürk ve Akcanlı, (2014) tarafından yapılan çalışmada da katılımcılar söz konusu eğitimin (\% 55) Üniversiteleri, (\% 54) TÜRMOB'u ve (\% 30) KGK olarak ifade etmişlerdir.

Tablo 3: Verilecek Bir Eğitimi Kimin Düzenlemesi Gerektiği

\begin{tabular}{|c|c|c|c|}
\hline & Frekans & $\%$ & \begin{tabular}{|c|} 
Sayı: 86 \\
Ortalama: 2,2558 \\
Standart Sapma: ,96022
\end{tabular} \\
\hline KGK & 12 & 14,0 & \\
\hline TÜRMOB & 56 & 65,1 & \\
\hline Maliye Bakanlığıl & 5 & 5,8 & \\
\hline Üniversite & 10 & 11,6 & \\
\hline Diğer & 3 & 3,5 & \\
\hline Toplam & 86 & 100,0 & \\
\hline
\end{tabular}

- Muhasebe Standartlarına ilişkin verilecek bir eğitime katılır mısınız? sorusuna meslek mensuplarının \% 91.9'u evet, \% 4.7'si hayır cevabını vermiştir.

- Meslek mensuplarının muhasebe standartlarını özümseyip finansal raporlama sürecine uygulamaları kaç yıl sürer?" sorusuna meslek mensuplarının verdiği yanıtların ortalaması Tablo 4'de görüldüğü üzere 3,825'dir. Bu da yaklaşık 4 yıla denk gelmektedir. Standart sapmanın da 1,247 olduğu dikkate alındığında bu görüş farklılığının diğer sorulardan daha fazla olduğunu göstermektedir. 
Tablo 4: Muhasebe Standartlarının Finansal Raporlama Sürecine Uygulanma Süresi

\begin{tabular}{|c|c|c|c|}
\hline & Frekans & $\%$ & \begin{tabular}{|c|} 
Say1: 86 \\
Ortalama: 3,8256 \\
Standart Sapma: 1,247
\end{tabular} \\
\hline $1 \mathrm{y} 1 \mathrm{l}$ & 5 & 5,8 & \\
\hline 2 y1l & 7 & 8,1 & \\
\hline $3 \mathrm{y} 1 \mathrm{l}$ & 24 & 27,9 & \\
\hline $4 \mathrm{y} 1 \mathrm{l}$ & 12 & 14,0 & \\
\hline 5 yıl ve üzeri & 38 & 44,2 & \\
\hline Toplam & 86 & 100,0 & \\
\hline
\end{tabular}

\section{Muhasebe Standartlarına Bakış Açıları}

Sizce muhasebe standartlarının uygulanması sürecinde karşılaşılacak sorunlar neler olacaktır? sorusunda Şekil 2'de görüldüğü gibi "meslek mensupları belirgin bir şekilde iş yükünün artmasını" $(\% 68,6)$ ön plana çıkarmaktadırlar. Devamında ise "kayıt dışı ekonominin getireceği sorunlar" (\% 46,5), "bilgi eksikliği”" (\% 43) ön plana çıkarılmaktadır (Bu soruda katılımcılar birden fazla seçeneği tercih edebilmektedir). Bu konuda Fidan ve Cinit (2013)'in yaptığı çalışmada muhasebe standartlarının meslek mensuplarının iş yükünü arttıracaktır ifadesinin en yüksek ortalama sahip olması bu çalışmadaki sonuçlarla örtüşmektedir. Ayrıca Yel ve Erdem (2015)'in yaptığı çalışmada da meslek mensupları TFRS'nin mesleği icra edenlerin iş yüklerini artıracağ 1 konusunda da bazı endişeler taşımakta olduğu sonucu çıkmıştır. Söz konusu çalışmaların sonucuna göre meslek mensupları TFRS uygulamaları ile birlikte iş yüklerinin daha da artacağını düşünmektedirler. Ayrıca bu çalışmaların sonucu, 2013'ten 2019 yılına kadar standart uygulamaları noktasında meslek mensuplarının iş yüklerinin artıracağı yönündeki kaygılarını azaltacak yeterli düzenlemelerin yapılmadığını ortaya koymaktadır.

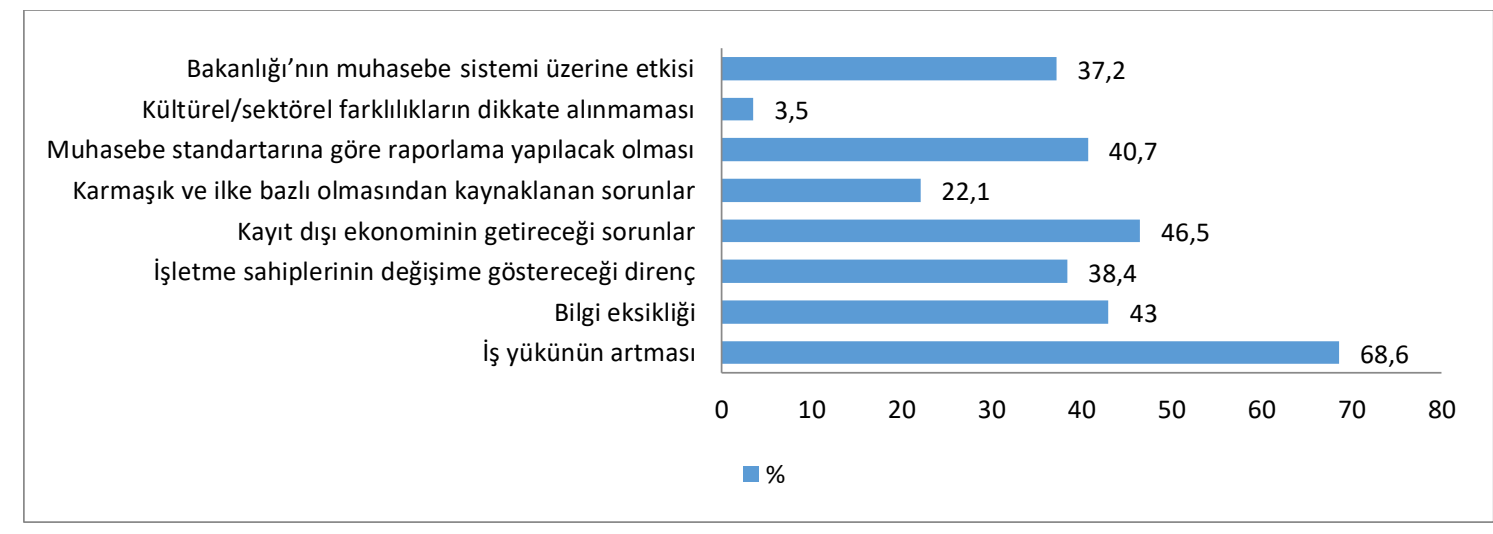

Şekil 2. Muhasebe Standartlarının Uygulanması Sürecinde Karşılaşılabilecek Sorunlar

Sizce muhasebe standartlarının uygulanmasının ülkemize katkısı ne olacaktır? sorusunda Şekil 3'de görüldüğü gibi "meslek mensupları belirgin bir şekilde kayıt dış1 ekonominin azalmasını" (\% 61,6) ifade etmişlerdir. Devamında ise "uygulamadaki çift başlılığın azalması" (\% $48,8)$, "kurumsal yönetimin yaygınlaşması" (\% 46,5) olduğu görülmektedir (Bu soruda katılımcılar birden fazla seçeneği tercih edebilmektedir). Yel ve Erdem (2015)'in yaptığ çalışmada "TFRS'nin finansal raporlamada standartlaşma sağlayacağ 1 ve kayıt dış1 ekonomiyi azaltacağ 1 şeklinde bir tespitin yapılmış" olması bu çalışmanın sonuçları ile örtüşmektedir. Ayrıca Şekil 3'te yer alan sonuçlar, kurumsal yönetimin yaygınlaşması ile beraber kurumlar arasındaki eşgüdümün 
sağlanmasının, uygulama birlikteliğine katkı sağlayacağını göstermektedir.

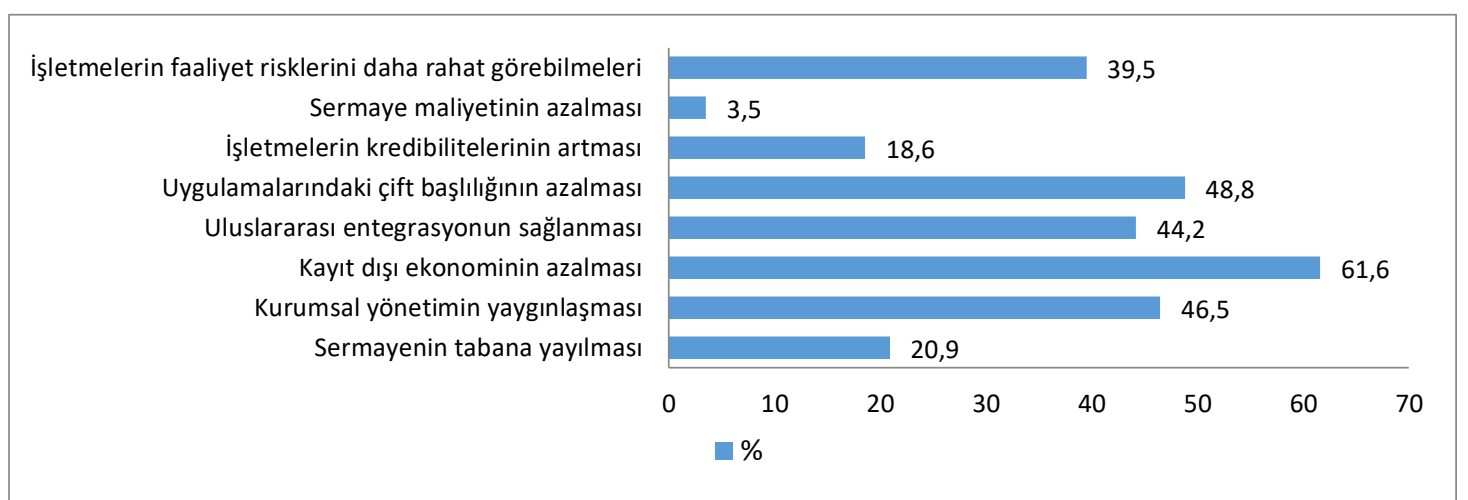

Şekil 3. Muhasebe Standartlarının Uygulanmasının Ülkeye Katkısı

Sizce muhasebe standartlarının uygulamaya geçiş sürecinin daha rahat atlatılması için neler yapılmalıdır? sorusunda Şekil 4'te görüldügü üzere belirgin bir şekilde meslek mensuplarının eğitimine önem vermelidir seçeneğinin $(\% 70,9)$ olduğu görülmektedir. Devamında ise işletme sahiplerinin konu hakkındaki bilgi düzeylerinin artırılması gerektiği $(\% 55,8)$, standartların daha iyi anlaşılmasının arttırılması $(\% 54,7)$ ve KGK, TÜRMOB ve Maliye Bakanlığ 1 arasındaki uyumun arttırılması $(\% 54,4)$ ön plana çıkmaktadır (Bu soruda katılımcılar birden fazla seçeneği tercih edebilmektedir). Bu konuda Bekçi ve Özdemir (2006)'in yaptığı çalışmada ortaya çıkan meslek mensuplarının eğitimlerinin yeterli olmadığı, standartların uygulanması ile birlikte iş yüklerinin artacağı ve muhasebe standartları metinlerinin anlaşılır olmadığı sonucunun ortaya çıkmış olması da Şekil 4'teki çalışma sonuçları ile örtüşmektedir. Bu sonuçlar, standartların uygulanmasına yönelik meslek mensuplarına verilen eğitimlerin ve standartların doğru algılanmadı̆̆ını ve anlaşılmasının halen daha yeterli olmadığını ortaya koymaktadır.

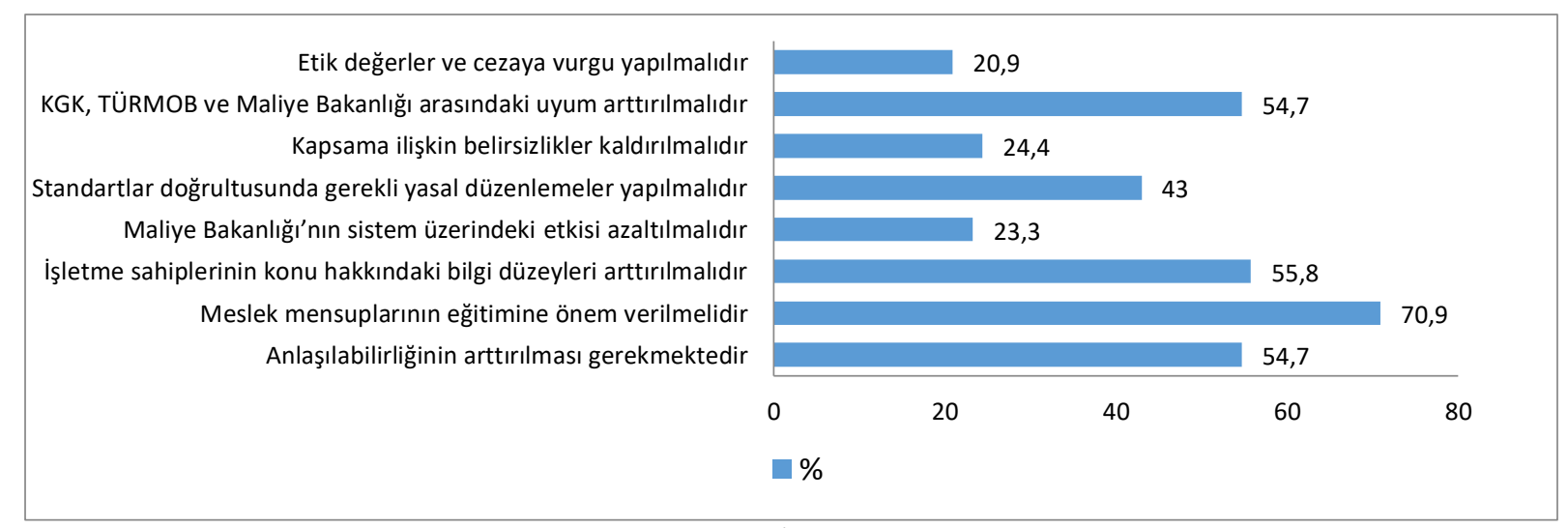

Şekil 4. Geçiş Sürecinin Rahat Atlatılması İçin Yapılması gerekenler

Ayrıca meslek mensuplarının muhasebe standartları hakkında bilgi düzeyi nasıl artırılabilir açık uçlu sorusuna katılımcıların \%59.3'nün uygulamalı eğitim verilmesi gerektiğini ifade etmeleri eğitim konusundaki Şekil 4'de yer alan sonuçlarla örtüşmektedir. 


\section{Meslek Mensuplarının Muhasebe Standartlarına İlişkin Görüşleri}

Tablo 5'de meslek mensuplarının muhasebe standartlarına yönelik yargılarına ait önem derecelerine ilişkin görüşlerini yansitan değerlendirmelerin beşli likert ölçeğine göre aritmetik ortalama puanları verilmiştir. Tablodaki değerlere göre en yüksek değer olarak öne çıkan "Muhasebe standartları işletmelerde kalifiye eleman ihtiyacını arttıracaktır", Muhasebe standartları ilgili taraflara daha tarafsız, doğru ve güvenilir bilgi sağlayacaktır", "Muhasebe standartlarının uygulamadaki başarısı için vergi mevzuatı ve muhasebe standartları mümkün olduğunca uyumlaştırılmalıdır", "Muhasebe standartlarının kullanımı işletmelerin bağımsız denetimlerini kolaylaştırır" ifadeleridir. Bu sonuçlar Şekil 1'deki sonuçlarla beraber değerlendirildiğinde katılımcıların iş yükünün artacağı yönündeki düşüncelerini destekleyen bir duruma bağlı olarak kalifiye eleman ihtiyacının artması birbirini desteklemektedir. Ayrıca "muhasebe standartlarının uygulamadaki başarısı için vergi mevzuatı ve muhasebe standartları mümkün olduğunca uyumlaştırılmalı" ifadesinin ortalamasının 4'e yakın olması Şekil 2'de yer alan sonuçlardan biri olan uygulamadaki çift başlılığın azalması ve Şekil 3'te yer alan "KGK, TÜRMOB ve Maliye Bakanlığı arasındaki uyumun arttırılması" ifadelerini desteklemektedir. Tablodaki değerlere göre en düşük değer olarak, "Muhasebe standartları doğrultusunda uygulamaya yönelik şimdiye kadar yapılan yasal düzenlemeler yeterlidir", "Muhasebe standartlarının uygulamadaki başarısı için cezalar ön plana çıkarılmalıdır" ve "Uluslararası muhasebe standartlarının Türkiye için tam metin aktarımı ile alınması uygundur" ifadeleridir. Düşük değer olarak öne çıkan söz konusu ifadeler hususundaki katılımcıları değerlendirmeleri standartların başarılı uygulamamasına katkı sağlamayacağını yönündedir.

Tablo 5: Meslek Mensuplarının Muhasebe Standartlarına İlişkin Likert Puanları

\begin{tabular}{|c|c|c|c|}
\hline & ÖNERMELER & Ort. & $\begin{array}{l}\text { S. } \\
\text { Sapm } \\
\text { a }\end{array}$ \\
\hline M10 & Yeni TTK'da muhasebe standartlarının ön plana çıkarılması doğrudur & 3.62 & 0.755 \\
\hline M11 & $\begin{array}{l}\text { TTK'da yapılan bir değişiklik ile muhasebe kayıtlarının vergi mevzuatına göre } \\
\text { tutulması, mali tabloların muhasebe standartlarına göre sunulması uygundur }\end{array}$ & 3.55 & 0.919 \\
\hline M12 & Muhasebe standartları gerekli bir düzenlemedir & 3.88 & 0.757 \\
\hline M13 & $\begin{array}{l}\text { Muhasebe standartları ilgili taraflara daha tarafsı, doğru ve güvenilir bilgi } \\
\text { sağlayacaktır }\end{array}$ & 4.07 & 0.761 \\
\hline M14 & Muhasebe standartları tüm sermaye işletmeleri için zorunlu olmalıdır & 3.88 & 0.992 \\
\hline M15 & $\begin{array}{l}\text { Uluslararası muhasebe standartlarının Türkiye için tam metin aktarımı ile } \\
\text { alınması uygundur }\end{array}$ & 3.35 & 1.013 \\
\hline M16 & Muhasebe standartlarının kullanımı işletmelerin bağımsız denetimlerini kolaylaşır & 3.98 & 0.702 \\
\hline M17 & \begin{tabular}{lllll|}
$\begin{array}{l}\text { Muhasebe } \\
\text { yaklaşımlarına bağlıdır }\end{array}$ & uygulamadaki & başarısı & işletme & sahiplerinin \\
\end{tabular} & 3.54 & 0.866 \\
\hline M18 & $\begin{array}{l}\text { Muhasebe standartlarının uygulamadaki başarısı için etik değerler ön plana } \\
\text { çıarılmalıdır }\end{array}$ & 3.54 & 0.932 \\
\hline M19 & $\begin{array}{l}\text { Muhasebe standartlarının } \\
\text { çıarılmalıdır }\end{array}$ & 2.80 & 1,055 \\
\hline M20 & $\begin{array}{l}\text { Muhasebe standartlarının uygulamadaki başarısı için vergi mevzuatı ve muhasebe } \\
\text { standartları mümkün olduguunca uyumlaştırılmalıdır }\end{array}$ & 3.97 & 0.751 \\
\hline M21 & $\begin{array}{llllll}\begin{array}{l}\text { Meslek mensuplarının } \\
\text { bulunmaktadır }\end{array} & \text { muhasebe } & \text { standartları alanında } & \text { bilgi eksikliği } \\
\end{array}$ & 3.89 & 0.840 \\
\hline M22 & Muhasebe standartları işletmelerde kalifiye eleman ihtiyacını arttıracaktır & 4.19 & 0.752 \\
\hline M23 & $\begin{array}{l}\text { Muhasebe standartları doğrultusunda uygulamaya yönelik şimdiye kadar yapılan } \\
\text { yasal düzenlemeler yeterlidir }\end{array}$ & 2.72 & 1.080 \\
\hline
\end{tabular}

Turkish Studies - Economy, 15(3) 


\section{İlişki}

\section{Meslek Mensuplarının Standartlarla İlgili Yargıları ile Kişisel Özellikleri Arasındaki}

Meslek mensuplarının standartlarla ilgili aşağıda yer alan yargıların bazı kişisel özelliklere göre farklılık gösterip göstermediğine ilişkin Anova ve t testi sonuçları Tablo 6'da sunulmuştur.

Tablo 6: Meslek Mensuplarının Muhasebe Standartlarına İlişkin Değerlendirmeler

\begin{tabular}{|c|c|c|c|c|c|c|c|c|}
\hline & \multicolumn{2}{|c|}{ Cinsiyet } & \multicolumn{2}{|c|}{ Yaş } & \multicolumn{2}{|c|}{ Eğitim } & \multicolumn{2}{|c|}{ Mesleki Kıdem } \\
\hline & $\mathbf{t}$ & p & f & p & f & p & f & p \\
\hline M10 & 0.035 & 0.972 & 0.606 & 0.613 & 3.249 & $0.026^{*}$ & 0.070 & 0.976 \\
\hline M11 & 0.548 & 0.585 & 1.872 & 0.141 & 1.396 & 0.250 & 1.167 & 0.328 \\
\hline M12 & -1.137 & 0.259 & 0.307 & 0.821 & 0.788 & 0.504 & 0.475 & 0.701 \\
\hline M13 & -0.424 & 0.673 & 0.207 & 0.891 & 2.497 & 0.066 & 2.162 & 0.099 \\
\hline M14 & -0.061 & 0.952 & 0.527 & 0.665 & 0.904 & 0.443 & 1.871 & 0.141 \\
\hline M15 & -0.758 & 0.451 & 0.356 & 0.785 & 0.808 & 0.493 & 0.683 & 0.565 \\
\hline M16 & -0.000 & 1.00 & 0.458 & 0.712 & 0.579 & 0.630 & 1.671 & 0.180 \\
\hline M17 & 0.496 & 0.621 & 0.690 & 0.561 & 2.927 & $\mathbf{0 . 0 3 9}^{*}$ & 1.456 & 0.234 \\
\hline M18 & -1.060 & 0.292 & 0.403 & 0.751 & 2.487 & 0.066 & 0.924 & 0.433 \\
\hline M19 & 1.853 & 0.067 & 0.951 & 0.420 & 0.593 & 0.622 & 2.802 & $0.045^{*}$ \\
\hline M20 & 1.546 & 0.126 & 2.163 & 0.099 & 1.890 & 0.138 & 0.924 & 0.433 \\
\hline M21 & 1.227 & 0.821 & 1.587 & 0.199 & 2.622 & 0.056 & 0.112 & 0.953 \\
\hline M22 & 2.612 & $0.011^{*}$ & 2.099 & 0.107 & 1.230 & 0.304 & 0.988 & 0.403 \\
\hline M23 & -0.939 & 0.351 & 1.382 & 0.254 & 1.992 & 0.122 & 0.158 & 0.924 \\
\hline
\end{tabular}

- Meslek mensuplarının muhasebe standartları ile ilgili olarak "Muhasebe standartları işletmelerde kalifiye eleman ihtiyacını arttıracaktır" önermesine ilişkin gerçekleştirilen $\mathrm{t}$ testi sonucuna göre cinsiyet ile söz konusu önerme arasında anlamlı bir ilişki olduğu belirlenmiştir $(\mathrm{p}<0,05) . \mathrm{Bu}$ sonuç erkeklerden ziyade bayanların standartların uygulanmasında kalifiye eleman ihtiyacının artacak olması önermesine daha çok katıldıklarını göstermektedir.

- Meslek mensuplarının muhasebe standartları ile ilgili olarak "Yeni TTK'da muhasebe standartlarının ön plana çıkarılması doğrudur" ile "Muhasebe standartlarının uygulamadaki başarısı işletme sahiplerinin yaklaşımlarına bağlıdır" önermesine ilişkin gerçekleştirilen $t$ testi sonuçlarına göre eğitim ile söz konusu önerme arasında anlamlı bir ilişki olduğu belirlenmiştir $(p<0,05)$.

- Meslek mensuplarının muhasebe standartları ile ilgili olarak "Muhasebe standartlarının uygulamadaki başarısı için cezalar ön plana çıkarılmalıdır" önermesine ilişkin gerçekleştirilen $t$ testi sonuçlarına göre mesleki kıdem ile söz konusu önerme arasında anlamlı bir ilişki olduğu belirlenmiştir $(\mathrm{p}<0,05)$. Bu sonuç kıdemli meslek mensuplarının 
başarının elde edilmesi noktasında tecrübelerinin bir sonucu olarak cezayı bir çözüm aracı olarak görmemelerini ortaya koymaktadır.

\section{Sonuç ve Öneriler}

Muhasebe standartlarıyla ilgili meslek mensuplarına yönelik yapılmış olan çalışmalar genel olarak ele alındığında çoğu çalışmada benzer sonuçların ortaya konulduğu bazı çalışmalarda ise zıt düşüncelerin ortaya çıktığı görülmektedir. En ilk çalışmanın yapıldığı 2002 yılından bugüne kadar yapılan çalışmalarda standartlarla ilgili ilk yıllarda yeterli bilgi düzeyinin olmadığı fakat son yıllarda bu bilgi düzeyinin arttığı gözlenmektedir. Bugüne kadar yapılan çalışmalar standartlar konusunun güncelliğini koruduğunu göstermektedir.

Çalışmada dikkat çeken hususlar şöyle özetlenebilir;

- Bilgi düzeyi ve eğitimin artması standartların meslek mensuplarınca içselleştirilerek uygulanmasını ve başarı düzeyini artıracaktır. Bu bağlamda TFRS uygulamalarına yönelik literatürdeki çalışmalarda ve bu çalışmada da öne çıkan kurumlar olan TÜRMOB ve Üniversite işbirliği ile eğitim faaliyetlerinin yapılması faydalı olabilir.

- Gerek bu çalışmada gerekse de literatürde ifade edilen çalışmalarda standartların tam anlamı ile uygulanmasının iş yükünü artıracağı ve fazladan iş yükü doğuracağ 1 ifade edilmiştir. E-Defter, e-Fatura gibi elektronik ortamda yapılan işlemlerin artması her ne kadar iş yükünün azaltmaya yönelik tedbirler olarak kabul edilse de elektronik ortamda yapılan işlemlerin muhasebeye konu olan tüm işletme faaliyetlerine yaygınlaştırılması ile ancak iş yükünün azalması beklenebilir.

- Çalışmada vurgulanan diğer bir konuda muhasebe uygulamaları ile ilgili kurumlar ve kanunlar arası uyumun arttırılmasının birçok problemi ortadan kaldıracak olmasıdır. Sonuç olarak vergi mevzuatı söz konusu muhasebe uygulamalarını etkilemektedir ve standartlar konusunda birliktelik sağlamak için de çeşitli çalışmalar yapılmaktadır. Şimdiye kadar tüm işletmeleri kapsayacak ve birden çok finansal tablo düzenlemeye engel olacak bazı düzenlemeler yapılmış olsa da (KOBİ TFRS ve BOBİ FRS gibi) hâlihazırda yapılan düzenlemeler meslek mensuplarının beklentilerini karşılamamaktadır. Diğer bir ifadeyle henüz beklenen düzeyde Vergi Usul Kanunu ile Türk Ticaret Kanunu koordinasyonunu içeren yasal düzenlemeler yapılmamıştır. Bu durum standartlar konusunun güncelliğinin devam ettiğini göstermektedir. Dolayısıyla yasal düzenlemelerin bir önce yapılması gerekir.

- Muhasebe standartları hakkındaki bilgi düzeyiniz nedir? sorusuna verilen yanıtların ortalaması ve likert ölçekte yer alan "Meslek mensuplarının muhasebe standartları alanında bilgi eksikliği bulunmaktadır" önermesinin ortalamasına göre standartlar konusunda eğitim verilmeye devam edilmesi gerekmektedir.

$\mathrm{Bu}$ çalışmada elde edilen veriler doğrultusunda bugüne kadar yapılan yasal düzenlemeler de dikkate alınarak meslek mensuplarına yönelik uygulama birlikteliği sağlayacak ya da farklılıkların neler olduğunu ortaya koyacak daha kapsamlı bir araştırma yapılabilir. Çalışmanın daha farklı bakış açılarıyla ele alınması araştırmacıları farklı sonuçlara götürecektir. 


\section{Kaynakça}

Acar, D., Bayri, O., Dalğar, H., Özdemir, O. (2009). Meslek Mensuplarının TMS/TFRS Uygulamalarına Bakış Açıları ve Farkındalık Düzeyleri: Bir Alan Araştırması, XXVIII. Türkiye Muhasebe Eğitimi Sempozyumu Yakın Gelecek ve Muhasebe Eğitimi, 20-24 Mayıs 2009, Alaçat1-Çeşme.

Ağca, A. (2003). Uluslararası Muhasebe Standartlarının Gelişmekte Olan Ülkelerde Uygulanabilirliği ve Kabul Görmüşlüğ̈̈, Yayınlanmamış Doktora Tezi, Anadolu Üniversitesi- Sosyal Bilimler Enstitüsü.

Akdoğan, N. (2003). AB'ye Üye Ülkeler Arasında Finansal Raporlama Uygulamalarında Uluslararası Standartlara Geçiş-Dördüncü ve Yedinci Yönerge Muhasebe Standartlarının IAS'e Yakınlaştırma Çalışmaları, Prof. Dr. Yüksel Koç Yalkın'a Armağan. SBF Yayın No:590, TÜRMOB Yayınları, No: 221: 33-36.

Akyüz, F. ve Yeşil, T. (2017). TFRS Açısından Muhasebe Meslek Mensuplarına Yönelik Yapılmış Olan Akademik Çalışmaların Değerlendirilmesi, Optimum Ekonomi ve Yönetim Bilimleri Dergisi, 4(1), 77-95.

Aktürk, A ve Akcanlı, F. (2013). Muhasebe Akademisyenlerinin Muhasebe Standartalrına Bakış Açıları ve Farkındalıkları Üzerine Bir Araştırma, MÖDAV, Vol. 15 Issue 4, p21-43.

Arsoy, A.P., Bora, T., ve Selimoğlu, S. (2014). Muhasebe Eğitimindeki Bilgi, Beceri ve Eğitim Tekniklerinin Gerekliliklerine İlişkin Beklentiler: Türkiye'deki Akademisyenlere ve Meslek Mensuplarına Yönelik Bir Araştırma, Uluslararası Yönetim İktisat ve İşletme Dergisi, Cilt 10, Say1 23, 121-136.

Bekçi, İ. (2007).Muhasebe Meslek Mensuplarının Türkiye Muhasebe Standartları Hakkındaki Görüşlerinin Değerlendirilmesine Yönelik Bir Araştırma, Muhasebe ve Denetime Bakış Dergisi, 22; 27-40.

Bekçi, İ., ve Özdemir, O., (2006). Muhasebe Standartlarının Oluşum Süreci ve Türkiye Finansal Raporlama Standartlarına Yönelik Muhasebe Meslek Mensuplarının Bakış Açıları Üzerine Bir Araştırma. Süleyman Demirel Üniversitesi, İ̈BF Dergisi, vol.11, 143-164.

Bengü, H , Çelik, F . (2014). Niğde İlindeki Muhasebe Meslek Mensuplarının Finansal Raporlama Standartlarına Bakış Açılarının Ampirik Olarak Değerlendirilmesi, Niğde Üniversitesi İktisadi ve İdari Bilimler Fakültesi Dergisi, 7 (1), 175-38.

Boyar, E. ve Güngörmüş, A. H. (2016). Muhasebe Meslek Mensuplarının Proaktif Kişilik Özelliklerinin, Kariyer Memnuniyeti İle UFRS' ye Bakış Açıları ve Bilgi Düzeyleri Üzerine Etkisi, Muhasebe ve Finansman Dergisi, 2(70), 55-66.

Civan, M., ve Kara, E. (2002). Muhasebe Standartlarının Muhasebe Mesleğinde Uygulanmasına Yönelik Bir Araştırma, Muhasebe ve Finansman Dergisi, 14, 74-81.

Elitaş, C., Karakoç, M. ve Özdemir, F.S. (2011). Muhasebe Meslek Mensupları Perspektifinden Türkiye Muhasebe Standartları, World Of IFRS Dergisi, 5, 1-13.

Erdoğan, M. ve Dinç, E. (2009). Türkiye Muhasebe Standartları v Muhasebe Meslek Mensuplarının Bilgi Düzeylerinin İncelenmesi, Muhasebe ve Finansman Dergisi, 3(439, 154-169.

Evci, S.(2008). Türkiye Muhasebe (Finansal Raporlama) Standartlarl ve Uygulanmasinda Yaşanan Sorunlar, Yayınlanmamış Yüksek Lisans Tezi, GÜ, SBE.

Fidan, M, Cinit, H. (2013). Türkiye Finansal Raporlama Standartları Çerçevesinde KOBİ Muhasebe Standartlarının Muhasebe Meslek Mensupları Tarafından Algı Düzeylerinin 
Tespitine Yönelik Uygulama (Eskişehir İli Örneği). Muhasebe ve Finansman Dergisi, (59), 39-60.

Gönen, S., Uğurluel, G.(2007). Türkiye'de Uluslararası Finansal Raporlama Standartları (UFRS) Uygulamalarına Geçişte Karşılaşılan Sorunlar ve Çözüm Önerileri, Vergi Dünyası Dergisi, Say1: 316, Aral1k,.229-236.

Hacıhasanoğlu, T., Karaca, N. ve Demirci, Ş. D. (2012). KOBİ'ler için TFRS' nin Getirdiği Yenilikler ve Uygulanabilirliği Üzerine Ankara İlinde Bir Araştırma, World Of IFRS Dergisi, 4, 1-22.

Kocamaz, H. (2012). Uluslararası Muhasebe Standartlarının Dünyada ve Türkiye'de Oluşum ve Gelişim Süreci, Kahramanmaraş Sütçü İmam Üniversitesi İktisadi ve İdari Bilimler Dergisi, 2(2), 105-120.

Kamu Gözetimi, Muhasebe ve Denetim Standartları Kurumu. Küçük ve Orta Büyüklükte İşletmeler İçin Türkiye Finansal Raporlama Standartları'nın (KOBİ TFRS). http://www.kgk.gov.tr/contents/files/KOBI_TFRS.pdf, (01.06.2019).

Sağlam, O., Sağlam, N. (2008). TMS-21 Kur Değişiminin Etkileri. Türkiye Muhasebe Standartları Uygulaması (Yorum-Açıklama-Örnekler), Sağlam, N., Şengel, S., Öztürk, B. (Ed.), 2. Baskı, Maliye ve Hukuk Yayınları, Ankara, 557-582.

Selimoğlu, S. K. (2008). Dünyadaki Uygulamalarından Hareketle Finansal Raporlama Standartlarının Finansal Tablolar Üzerindeki Genel Etkileri, XII. Türkiye Muhasebe Standartları Konferansl.

Şen, İ. K. (2006). Borçlanma Maliyetlerinin Türk Mevzuatı, Sermaye Piyasası Mevzuatı ve Uluslararast Muhasebe Standartları Kapsamında Incelenmesi, Yüksek Lisans Tezi, Marmara Üniversitesi.

Uysal, Ö. (2006). Uluslar arası Muhasebe Standartlarının Oluşum Süreci: IASC ve Önde Gelen Ulusal ve Uluslar arası Örgütler, Muhasebe ve Denetime Baklş Dergisi, Y11:5, Sayı:17, 8891.

Yazıc1, M. (2003). Muhasebe Standardının Tanımı, MUFAD Muhasebe ve Finansman Dergisi, Say1:18, Nisan: 33-37.

Yel, T. A. ve Erdem, M. S. (2015). Muhasebe Meslek Mensuplarının UFRS Hakkındaki Farkındalık Düzeylerinin Tespiti: Bolu İli Örneği, Ekonomik ve Sosyal Araştırmalar Dergisi, 11(2), 217-231.

http://www.denetimnet.net/UserFiles/Documents/2011/Yeni_TTK_ve_UFRS_uyumlu_TMS_ye_g ecis.pdf. 